\title{
Fungal Plant Pathogens Associated with Emerging Crops in North America: A Challenge for Plant Health Professionals
}

Frank M. Dugan, ${ }^{\dagger}$ Shari L. Lupien, and Jinguo Hu, USDA-ARS Western Regional Plant Introduction Station, Washington State University, Pullman

Accepted for publication 20 October 2017.

\begin{abstract}
"Emerging crops" is a term typically applied to ethnic food plants or to plants used in traditional or ethnic medicine, some of which are becoming viable niche markets in North America. Information on crop protection of these plants is often scarce to lacking. Literature on diagnosis and management of fungal diseases of these crops in North America is concisely reviewed, with information gaps identified. Emphasis is placed on crops comprising recent niche

markets for Asian, African, Oceanian, or Latino immigrants. Emerging crops are often tied to economic activities of immigrant populations. Crops of immigrants from Asia, Africa, Latin America, and Oceania are contrasted with crops established by immigrants of European origins, plants usually familiar to North American plant health professionals, and with Native American food and medicinal plants, some of which are experiencing a renaissance as emerging crops.
\end{abstract}

In the United States, recent immigrants and those to whom they have imparted their culinary tastes have created demand for new crops. Variously prefaced by the descriptors "ethnic," "specialty," or "emerging," these crops represent growing niche markets (Govindasamy et al. 2010; Molinar 2012; Wang and Cerkauskas 1999). Some such crops are primarily food crops, whereas others are primarily medicinal, although the distinction is not invariant for many ethnic groups (e.g., Corlett et al. 2003). For some crops, such as chili peppers, use is now widespread and the fruit highly familiar ("mainstream"). This familiarity can be partly attributed to increases in the populations of Asian and Hispanic immigrants but also to acceptance within the general population (Gandonou and Waliczek 2013). Other emerging crops have been initiated from agricultural activities or culinary preferences of recent Oceanian or African immigrants, or a smaller number from European immigrants or Native American populations as discussed later.

The introduction of plants as specialty crops or as breeding materials for American agriculture is facilitated by the U.S. Department of Agriculture's National Plant Germplasm System (NPGS, https://www.ars-grin.gov/npgs/), which comprises regional plant introduction stations and crop-specific genebanks or repositories. Crop curators for the NPGS are currently building collections of tef (Eragrostis tef), quinoa (Chenopodium quinoa), faba bean (Vicia faba), chia (Salvia hispanica), amaranth (Amaranthus spp.), fennel (Foeniculum vulgare), and other plants (New Crops Report, https:// www.ars-grin.gov/npgs/cgc_reports/newcrops $2 . h t m)$. Such efforts can result in firm establishment of crops once regarded as emerging.

The USDA-ARS Western Regional Plant Introduction Station (WRPIS, part of the NPGS) and the USDA-ARS Grain Legume Genetics unit long collaborated on introduction of chickpea (Cicer arietinum) as an alternative regional crop in rotation with wheat and

${ }^{\dagger}$ Corresponding author: F. Dugan; E-mail: frank.dugan@ars.usda.gov

This article is in the public domain and not copyrightable. It may be freely reprinted with customary crediting of the source. The American Phytopathological Society, 2017. barley (Muehlbauer et al. 1982), but the crop's primary disease, Ascochyta blight (causal agent, Ascochyta rabiei), followed in 1983 (Kaiser and Muehlbauer 1984). The sexual state of the pathogen was soon detected and its role in disease transmission explained (Kaiser and Hannan 1987). Today the crop is an established, major contributor to regional agriculture in the Pacific Northwest (PNW), in the high plains of the United States and Canada, and in California (NASS 2017). Diseases are well described, and cost-effective management of $A$. rabiei is achieved via seed treatment, cultural practices, and partial resistance (Chen et al. 2011; Harveson et al. 2011). In strong contrast, crop protection information on many crops still regarded as emerging continues to lag.

The objectives of this review are to concisely summarize available information on fungal plant pathogens of specific emerging crops by provision of cited literature (Table 1) and to provide further examples and status reports for "ethnic" vegetables and for faba bean, an emerging crop in the U.S. PNW. Situations pertinent to different groups of emerging crops, each such group being affiliated with one or more immigrant or native populations, are briefly contrasted.

\section{INFORMATION DEFICITS AND PHYTOSANITARY RISKS}

As with all crops, emerging crops have disease problems. These problems are conveniently, if somewhat artificially, divided into two categories: (i) deficits in phytopathological information and (ii) phytosanitary risks associated with movement of propagative material. Even when suitable crops and cultivars are available, inadequate information on diseases may limit crop production (Kim 2016). A recent detailed economic analysis of ethnic crops referred to crop protection only by stating "more applied studies are needed" (Sciarappa et al. 2016). Moreover, there have been concerns that seeds of specialty crops, imported in the absence of a phytosanitary certificate, may contain pests or pathogens that pose a threat to production (Wang and Cerkauskas 1999). Interception of pests (including pathogens) associated with seeds and other propagation materials illicitly transported to the United States comprises 7\% of interception records in the USDA Animal and Plant Health Inspection Service Port Information Network database (McCullough et al. 
TABLE 1

North American ${ }^{a}$ records for fungal diseases of selected ethnic and specialty food and medicinal crops

Crop

Aloe vera

Arugula, Eruca sativa

Bok choy, Brassica campestris,

Chinensis group var. communis

Chervil, Anthriscus cerefolium

Chickory, Italian dandelion, radicchio, Cichorium intybus

Chinese and Napa cabbage, Brassica campestris, Pekinensis group var. cephalata $^{\mathrm{c}}$

Chinese broccoli, Chinese kale, Brassica alboglabra (Brassica oleracea var. alboglabra ${ }^{\mathrm{c}}$ )

Chinese leaf mustard Brassica juncea var. foliosa ${ }^{\mathrm{c}}$

\section{Disease, agent}

Leaf spot, Alternaria alternata

Root rot, Rhizoctonia solani

Southern blight, Sclerotium rolfsii

Anthracnose, Colletotrichum higginsianum

Downy mildew, Peronospora parasitica

White rust, Albugo candida

Alternaria leaf spot Alternaria brassicae, A. brassicola

Club root, Plasmodiophora brassicae

Downy mildew, Peronospora parasitica

Foliar blight, Rhizoctonia solani

Verticillium wilt, Verticillium sp.

White leaf spot,

Pseudocercosporella capsellae

White rust, Albugo candida

Powdery mildew, Erysiphe heraclei

Stem and crown rot, Sclerotinia sclerotiorum

Downy mildew, Bremia lactucae

Leaf spots, Alternaria cichorii, A. sonchi, A. tenuissima, Cercospora cichorii, Ramularia inaequale

Powdery mildew, Golovinomyces (Erysiphe) cichoracearum

Root rots, Phymatotrichum omnivorum, Phytophthora cryptogea, Sclerotinia sclerotiorum, S. minor

Rust, Puccinia hieracii, Puccinia littoralis

Southern blight, Sclerotium rolfsii

Alternaria leaf spot, Alternaria brassicae, A. brassicola

Downy mildew, Peronospora parasitica

Foliar blight, Rhizoctonia solani

Verticillium wilt, Verticillium sp.

White leaf spot,

Pseudocercosporella capsellae

White rust, Albugo candida

Downy mildew, Peronospora parasitica

White leaf spot,

Pseudocercosporella capsellae

White rust, Albugo candida

Alternaria leaf spot, Alternaria brassicae

Club root, Plasmodiophora brassicae

White rust, Albugo candida

Ethnic affiliation(s) of crop

References

Multiple, Latino

Mediterranean

European, Italian

East Asian

East Asian

East Asian
Cerkauskas et al. (1998)

da Silva and Singh (2012); Farr and Rossman (n.d.) ${ }^{\mathrm{b}}$

Koike (1998); Patel et al. (2014); Scheck and Koike (1999)

Cerkauskas et al. (1998); Koike et al. (2007); Zhang et al. (2013)

Koike (1999); Koike and Saenz (2004)

Farr and Rossman (n.d.); Koike and Butler (1998)

Cerkauskas et al. (1998); Koike et al. (2007)

Cerkauskas et al. (1998)

(Continued on next page)

\footnotetext{
${ }^{\mathrm{a}}$ Including the state of Hawaii.

${ }^{\mathrm{b}}$ Records in Farr and Rossman (n.d.) are not restricted to pathogens. Only records from unequivocally pathogenic fungi are here included, although other records, not shown, may indicate the origin as "leaf spot" or other symptoms on a given host. Records of special importance are individually listed in spite of inclusion in Farr and Rossman (n.d.).

${ }^{\mathrm{c}}$ Records in Farr and Rossman (n.d.) seldom pertain to cultivars (which can vary greatly in susceptibility) but are recorded at the level of host species.
} 
Chinese radish, daikon, Raphanus sativus, Longipinnatus group

Chinese winter melon Benincasa hispida

Cilantro (Chinese parsley, Mexican parsley), Coriandrum sativum

Corn-salad, lamb's lettuce, Valerianella locusta

Echinacea, coneflower, Echinacea angustifolia, E. pallida, E. purpurea

Faba bean, fava bean, horse bean, Vicia faba

Fennel, Foeniculum vulgare
White leaf spot, Pseudocercosporella East Asian capsellae

Anthracnose, Colletotrichum spp. East Asian

Downy mildew,

Pseudoperonospora cubensis

Root rot, Fusarium solani

Verticillium wilt, Verticillium dahliae

Fusarium wilt, Fusarium oxysporum f. sp. corianderii

Root rots, Phytophthora parasitica, Rhizoctonia sp.

Downy mildew, Peronospora European valerianellae

Powdery mildew, Golovinomyces orontii

Root rot, Thielaviopsis basicola

Stem and crown rot, Sclerotinia minor

Alternaria leaf spot, Alternaria spp. Native American

Damping off, Alternaria spp.,

Fusarium spp., Pythium spp., Rhizoctonia solani

Fusarium root and crown rot, Fusarium oxysporum, Fusarium spp.

Gray mold, Botrytis cinerea

Leaf spot, Septoria spp.

Powdery mildew, Golovinomyces cichoracearum

Sclerotinia blight, Sclerotinia stem and root rot, Sclerotinia sclerotiorum

Smut, Entyloma spp.

Anthracnose, Colletotrichum villosum

Ascochyta blight, Ascochyta fabae (Canada)

Chocolate spot, Botrytis cinerea, $B$. fabae

Leaf spot, Ascochyta pisi

Powdery mildew, Erysiphe trifoliorum (artificial inoculation)

Root rots, Phymatotrichum omniforum, Phytophthora cactorum, Phytophthora capsici, Rhizoctonia solani

Rust, Uromyces fabae

Southern blight, Sclerotium rolfsii Stem rot, Sclerotinia sclerotiorum Fusarium stem and crown rot, Fusarium avenaceum

Gray mold, Botrytis cinerea

Leaf spot, Cercosporidium punctum

Root rot, Phymatotrichum omnivorum, Rhizoctonia solani

Stem rot, Sclerotinia minor
East Asian, Latino, Southern European

Mediterranean, Middle Eastern, Asian

Multiple, especially South Asian, Middle Eastern, Mediterranean
Cerkauskas et al. (1998); Koike and Molinar (1997)

Farr and Rossman (n.d.); Ji et al. (2012); Koike et al. (2007)

Koike and Gordon (2005); Koike et al. (2007); Raabe et al. (1981)

Koike (2003, 2008); Koike and Saenz (2004); Stanghellini et al. (1990)

Chang et al. (1999); Farr and Rossman (n.d.); Peichowski et al. (1997); Sholberg and Li (1999).

Attanayake et al. (2010); Erwin and Ribeiro (1996); Farr and Rossman (n.d.)

Farr and Rossman (n.d.); Koike (1994); Koike et al. (1992, 2012) 
Fenugreek, Trigonella foenumgraecum

Ginseng, Panax quinquefolius

Japanese mustard, Brassica campestris subsp. nipposinica ${ }^{\mathrm{c}}$

Malabar spinach, Basella alba

Noni, Morinda citrifolia

Pak choy, Brassica campestris,

Chinensis group var. communis ${ }^{\mathrm{c}}$

Quinoa, Chenopodium quinoa

Rapini (rappini), broccoli raab, Brassica rapa subsp. rapa, ruvo group $^{\mathrm{c}}$

Shiso, Perilla frutescens

Ascochyta blight, Peyronellaea pinodes

Downy mildew, Peronospora trigonellae

Gray mold, Botrytis cinerea

Leaf spot, Cercospora transversiana

Powdery mildew, Erysiphe pisi

Smut, Entyloma spp.

Alternaria blight, Alternaria panax

Anthracnose, Colletotricum spp.

Black root, Thielaviopsis basicola

Damping off, Pythium sp.,

Rhizoctonia solani

Gray mold, Botrytis cinerea

Root rot, Cylindrocarpon

destructans, Phytophthora spp.,

Sclerotinia panacis, $S$.

sclerotiorum

Rusted root, Rhexocercosporidium panacis

Wilt, Verticillium albo-atrum

Tah tsai, Brassica campestris subsp. White rust, Albugo candida narinosa ${ }^{\mathrm{c}}$

Tomatillo, Physalis ixocarpa

St. John's wort, Hypericum perforatum

East Asian
Mediterranean, South Asian

Farr and Rossman (n.d.);

McPartland and Hosoya (1998);

Punja (1997); Putnam and du Toit (2003); Reeleder (2007)
White rust, Albugo candida

Leaf spot, Bipolaris sp., Cercospora African, Asian sp.

Fruit rot, Mucor circinelloides

Alternaria leaf spot, Alternaria brassicae

White leaf spot,

Pseudocercosporella capsellae

Ascochyta leaf spot, Ascochyta sp.

Downy mildew, Peronospora variabilis

Passalora leaf spot, Passalora dubia

White rust, Albugo candida

Alternaria leaf spot, Alternaria

brassicae A. brassicola

Gray mold, Botrytis cinerea

Leaf spot, Cristulariella pyramidalis

East Asian

East Asian

East Asian

Andean

Southern European

East Asian

East Asian

Powdery mildew, Sphaerotheca fusca Latino Early blight, Phytophthora infestans

Leaf blight, stem dieback, Diploceras European hypericinum

Powdery mildew, cf. Microsphaera hypericacearum

Rust, Uromyces hyperici

Southern blight Sclerotium rolfsii
Farr and Rossman (n.d.); Habibi et al. (2016); Richardson (1990); Rooney-Latham et al. (2009)
Testen and Backman (2012); Testen et al. $(2013 a, 2013 b)$

Koike (1997); Koike et al. (2007)

Farr and Rossman (n.d.); Koike and Daugovish (2012)

Koike (1996)

Farr and Rossman (n.d.); Koike and Smith (1998)

Farr and Rossman (n.d.); Glawe (2004); Keinath et al. (1999); Putnam (2000)
2006). Anecdotal instances of such illicit importation are pertinent and abundant: for example, "many seeds were smuggled in" (Coulter 2006) and "bulbs and seeds, sometimes smuggled across borders by friends and relatives" (Hondagneu-Sotelo 2014). Pathogens in commercially imported (and inspected) seed, including seed moved by plant germplasm centers, are of equal concern (McGee 1997) but more frequently pertain to familiar staple crops whose diseases are relatively familiar to North American diagnosticians and other plant health professionals and for which screening methods are readily available. Given the relative lack of information on production of emerging crops, and given the problem of unauthorized importation of propagative material, a critical first step for plant health professionals is locating existing information on diseases of these less familiar, emerging crops. 


\section{DISEASE RECORDS IN LITERATURE}

Plant pathologists report novel disease incidents on emerging crops in a variety of peer-reviewed venues, including this journal. For several English-language venues, reports concerning plant pathogenic fungi are incorporated into the searchable databases of the USDAARS Systematic Mycology and Microbiology Laboratory (Farr and Rossman n.d., henceforth SMML). This resource, addressing fungi on many plants (including ethnic food plants and plants used in traditional medicines), is useful and widely cited. However, fungi recorded in the SMML are not invariably pathogenic to the hosts listed, and the literature provided for each record should be consulted if pathogenicity is to be addressed. For example, SMML records for fenugreek (Trigonella foenum-graecum), now important in U.S. east coast ethnic markets (Govindasamy et al. 2010), comprise over 40 fungi. Some are obligate pathogens (powdery mildews, downy mildews, and rusts), but others are fungi better known for saprophytic habit (species in Alternaria, Cladosporium, Epicoccum, Gliocladium, etc.), and yet others can be seen to be pathogens by inspection of the literature provided, for example, Leppik (1960) for Cercospora traversiana. SMML conveniently lists the country and/or state for each record. Although indispensable for diagnosticians and others, readers should not assume SMML records are comprehensive, available for all locales, and contemporary. For example, records for fenugreek are mostly from foreign sources, and those for North America, although relevant, are decades old (Leppik 1960). SMML lists 22 names for fungi on tef (teff, Eragrostis tef), but none of the records are for North America, although tef is now grown in multiple locales in the United States as a specialty crop (Girma et al. 2012). For lablab bean (Lablab purpureus), there are 200 records in SMML, but only two (rusts from Puerto Rico) pertain to the United States, where the bean has been introduced (Imbruce 2007). Breadfruit (Artocarpus altilis) is grown in Hawaii, in large part to satisfy culinary preferences of immigrants from Somoa, Tonga, and the Marshall Islands (Ragone 1997). Ragone (1997) has a short section on diseases and pests, including a few fungal genera and one fungal species. SMML currently contains records of only four fungi from breadfruit in Hawaii, with the remaining 42 records from elsewhere, either a tribute to successful exclusion of fungi from breadfruit in Hawaii or just incomplete documentation. Although SMML is indispensable, its limitations must be addressed by exploiting other resources, of which we address important examples below.

\section{THE EXAMPLE OF "ETHNIC" VEGETABLES}

Occasionally, comprehensive surveys are published for a given crop or category of crops. For "oriental vegetables" grown in Ontario, Cerkauskas et al. (1998) reported pathogens on Chinese and Napa cabbage, bok choy, Chinese leaf mustard, pak choy, Chinese broccoli, and Chinese radish (Table 1). Some of these vegetable specialty crops were also addressed in Koike et al. (2007), along with vegetables more frequently used in mainstream North American diets. These crops, such as flowering Chinese cabbage (Brassica campestris ssp. chinensis), are also grown in the United States (Govindasamy et al. 2010; Zhang et al. 2013), and experimental pest and disease management tools have been assessed (Zhang et al. 2013). However, as seen below, management tools are often suboptimal to lacking. This situation contrasts with the introduction of chickpea addressed above, for which management options are now well developed. Moreover, chickpea is a single species, although there are desi and kabuli varieties (Chen et al. 2011). "Oriental vegetables" are primarily cabbage family (Brassicaceae), but ethnic vegetables occur in other plant families, have numerous plant taxa (including cultivars), were often recently introduced, and have diseases that are correspondingly diverse, as are pathways for elicit seed importation (Wang and Cerkauskas 1999). Acreage for individual plantings of vegetables is seldom as large as for pulses, and this will have impacts on management options.

The situation can be illustrated via some extension publications focusing on commercial production of such crops: for example, Tubene and Myers (2008) for amaranth, cilantro (Coriandrum sativum), and tomatillo (Physalis philadelphica, P. ixocarpa). But pest and disease management of these crops is not addressed with specifics in Tubene and Myers (2008), although "leaf spot" and "white rust" of amaranth are mentioned. An alternative reference from the same institution (University of Maryland Extension 2013) does not address diseases of amaranth, cilantro, or tomatillo, but the reference provides recommendations for fungicidal seed treatment of Chinese cabbage, okra (Abelmoschus esculentus), and peppers and for control of "downy mildew" (not further specified) in "mustard greens" (usually indicating Brassica juncea). Fungicide recommendations (including seed treatment) are provided for Chinese cabbage, mustard greens, okra, and peppers by Wyenandt et al. (2017). For additional sources on Chinese cabbage, mustard greens, tomatillo, and amaranth, see Table 1.

Adekunle et al. (2011) noted for Ontario, "much research is needed to determine ... how pests of ECV [ethnocultural vegetables] can be controlled ... there are still no registered pest control products available for ECVs, which means they have to be grown organically." Pests are one of the main constraints in production of the ethnocultural vegetable crop bitter melon (Momordica charantia), a medicinal and food plant, in Ontario (Nawaratne 2012). In the absence of recommendations for ethnic crops, some growers have used pesticides that are recommended for related major crops, and consequently experimental studies document the comparative persistence of fungicides and other chemicals on such ethnic crops (Ripley et al. 2003). It is difficult to ascertain the degree to which pesticides are actually used in ethnic crops in North America, although a history of pesticide registrations for minor crops via the IR-4 program is available online (https://portal.nifa.usda.gov/web/ crisprojectpages/0028044-enabling-pesticide-registrations-forspecialty-crops-and-minor-uses.html). In a cooperative study by the USDA and UNESCO, Hightower and Brennen (2013) explicitly indicated pest, disease, and weed management as the leading priority of immigrant farmer training programs, but they did not provide specifics, although some of their citations indicated relevant crops and markets (e.g., lablab beans, water spinach, amaranth, and bok choy in an ethnic market in San Diego) (Brown 2011).

Information on disease management of ethnic vegetables is sometimes available online, but it is not necessarily open access nor directed toward North American audiences. The Australian sites AusVeg (https://ausveg.com.au/) and Asian Vegetables (https://www.daf.qld. gov.au/plants/fruit-and-vegetables/vegetables/asian-vegetables) provide common names for pests and diseases. The extent to which agricultural chemicals are registered for control varies by country, so readers should not assume that registered uses in Australia or elsewhere have their equivalents in North America.

\section{THE EXAMPLE OF FABA BEAN AT WRPIS}

As stated for chickpea above, it has been the historical mission of plant introduction stations to research possibilities for improving U.S. agriculture via the introduction of suitable plant germplasm (Hodge and Erlanson 1956; Hyland 1977). One such current program at WRPIS focuses on faba bean (Vicia faba). In North America, specialty grocery stores stock imported canned or dry faba beans or faba bean snacks (Fig. 1), but local fresh faba beans are becoming increasingly available (Fig. 2) as faba bean is grown by small and medium-scale farmers, primarily for immigrant and ethnic consumers (Miles and Hu 2014). Faba bean is an old crop, perhaps one of the 


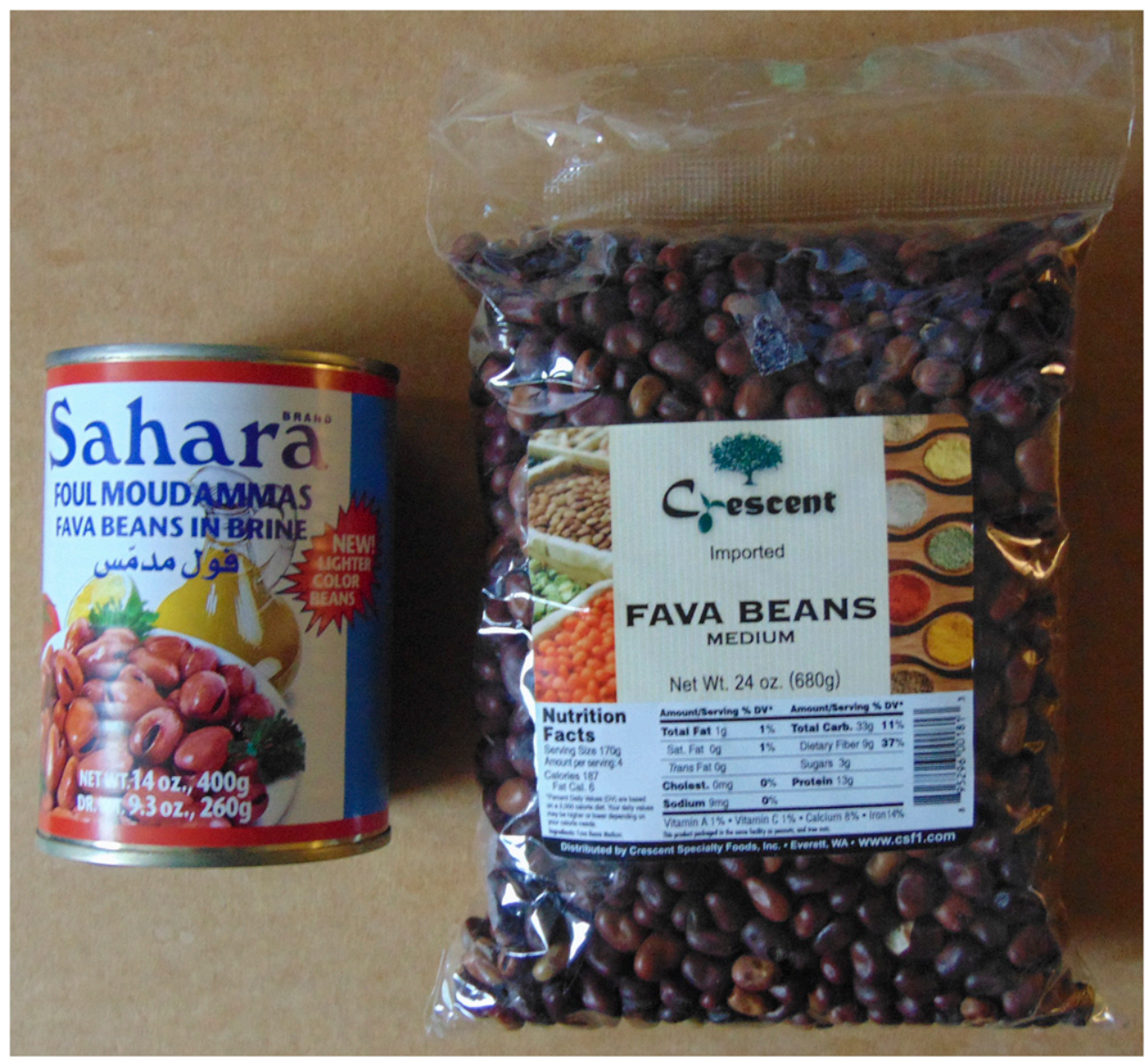

FIGURE 1

Imported canned (left) and dry (right) faba beans from a retail "international market" in Pullman, Washington.

foundation crops of the Neolithic, although no wild progenitors have been found (Muehlbauer et al. 1994). It was for millennia cultivated in the Middle East, Europe, and Asia (Ladizinsky and Abbo 2015).

Enhancing germplasm of faba bean appropriate for cultivation in the inland PNW makes up a significant portion of research at WRPIS (Landry et al. 2015a, 2016). Cold hardiness is important for the inland PNW, but faba bean has been grown for local markets for some time in the more moderate climate of coastal Oregon and Washington. Advances in cold hardiness have been achieved (Landry et al. 2015b), but plant health problems have also arisen.

In particular, plantings in both western and eastern Washington bore symptoms typical of Ascochyta blight (caused by Ascochyta fabae), previously reported in North America from Canada (SMML). This is not unanticipated and is analogous to the experience with chickpea in the PNW, described earlier. Representative isolate Vfaba\#1:2013 from Whitman County matched the description of A. fabae in Punithalingam and Holliday (1975), and following methods in Berbee et al. (1999) the glyceraldehyde-3-phosphate dehydrogenase gene sequence had $100 \%$ identity with $A$. fabae (GenBank accession no. DQ383959) (Peever et al. 2007). When faba bean seedlings were inoculated with suspensions of conidia of Vfaba\#1:2013, lesions typical of Ascochyta blight of faba bean (Richardson 2008) were produced on inoculated plants (but not on mock-inoculated controls) in each of two trials, and the fungus was recovered into pure culture in each trial. Plantings from Washington State also bore symptoms of chocolate spot (caused by Botrytis fabae and $B$. cinerea), previously reported from Alaska, California, Georgia,
North Carolina, and New York (SMML), and we have recovered Botrytis sp. isolates (not yet further identified) from symptomatic tissue. We are aware of the proliferation of new Botrytis species, including one reported from faba bean (Zhang et al. 2010). In addition to A. fabae and Botrytis sp., long recognized as pathogenic to $V$. faba (e.g., Davidson et al. 2004; Kaiser et al. 1997), we are currently conducting pathogenicity tests on faba bean using isolates of other fungi obtained from faba bean in Washington State. The North Dakota Department of Agriculture, partnering with North Dakota State University, is concurrently investigating diseases of faba bean in that region (USDA Specialty Crop Block Grant Program 2016). We hope that further development of cold-tolerant cultivars, site-appropriate cultural practices, and enhanced information on diseases and pests will address needs of growers who want to adopt faba bean production.

\section{CONTRASTS AND COMMONALITIES}

This brief review has addressed Asian, African, Oceanian, and Latin American crop plants, but readers are reminded that European immigrants also brought their own traditions (and plants), including plant-based medicines. However, not all introduced crops are equally problematic for plant health professionals. For example, medicinal plants from Asian traditions can be problematic. Information is either directed toward growing conditions and practices specific to Asian countries or is not consistently available in English. Extensive literature, in English, on diseases and pests of medicinal plants exists for South Asia, including recommendations for organic control (e.g., Chavan and Korekar 2011; Gahukar 2012; Gupta et al. 2010). There 


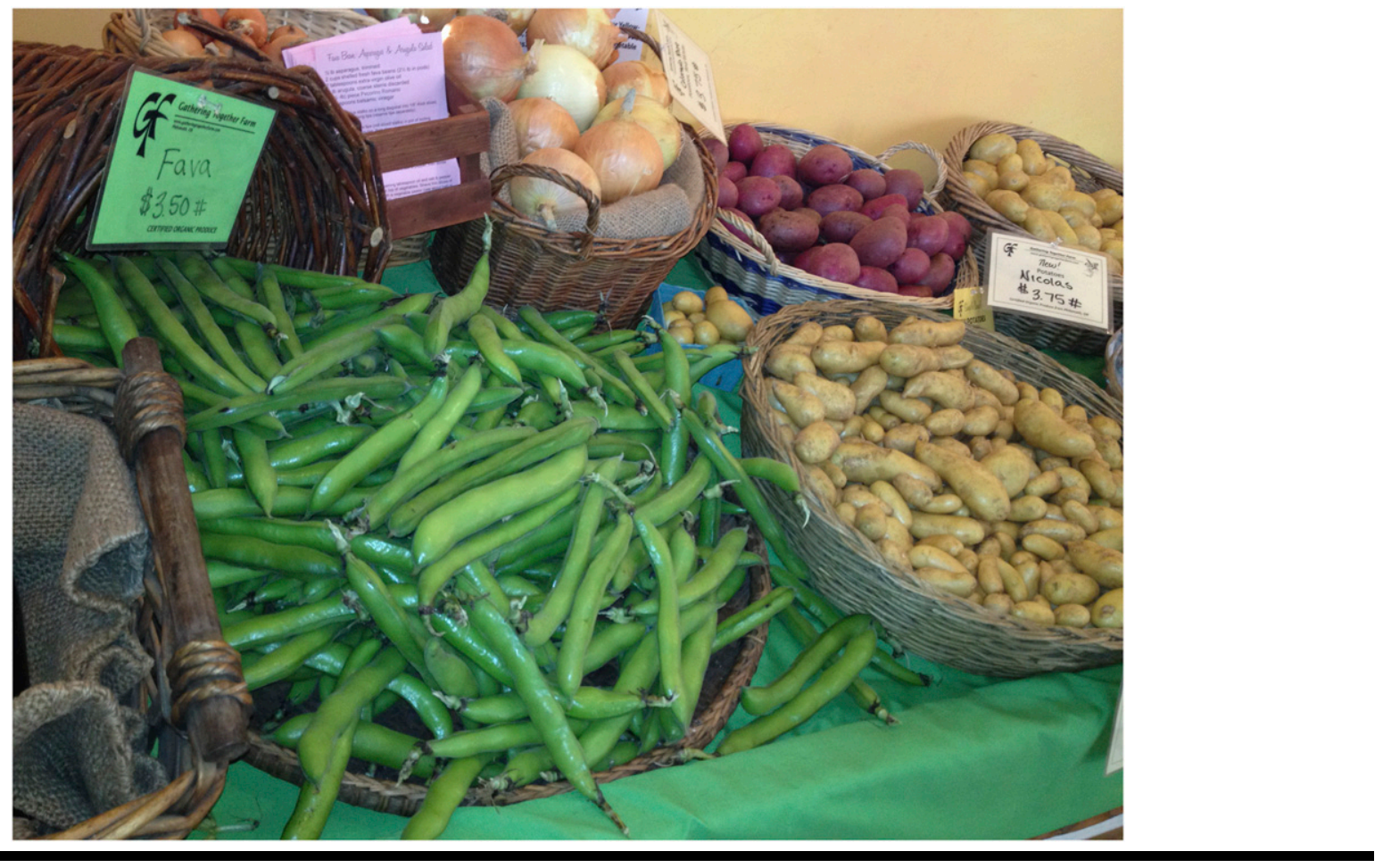

FIGURE 2

Fresh, local faba beans at an organic food store near Corvallis, Oregon.

are significant contributions, in English, from East Asia as well (e.g., Ni et al. 2010; Sano et al. 2009), but the majority of such literature is in Asian languages (e.g., Chen et al. 2006). In the absence of analogous literature for North America, and better documentation of the pathogens and pests involved, there will be slow progress on formulating management recommendations for these crops in North American environments. By contrast with such crops, plants used by European immigrants tended to be familiar to established European populations here (even if some medicinal uses were novel), and they seldom constituted emerging crops. For example, plants used by Norwegian immigrants to North America for medicinal applications include beets (Beta vulgaris), hops (Humulus lupulus), mustards (Brassica spp.), onions (Allium cepa), potatoes (Solanum tuberosum), and flax (Linum usitatissimum) (Stokker 2007). Ukrainian immigrants treated maladies with wormwood (Artemisia spp.), flax, lowbush cranberry (lingonberry, Vaccinium vitis-idaea), poppy (Papaver spp.), and garlic (Allium sativum) (Mucz 2012). What these latter plants have in common is that they are in the European crop tradition, or if medicinal (e.g., yarrow, Achillea millefolium; chamomile, Matricaria spp.), were often familiar to North Americans of European descent. They are often endemic (rather than native) to North America, and are frequently harvested from the wild. These patterns are repeated for Slavic immigrants; for example, beets, onions, and garlic are regarded as medicinal as well as culinary, and other medicinal plants (dandelion, Taraxacum spp.; St. John's wort, Hypericum perforatum; Calendula spp., marigolds) are gathered from the wild or home gardens (Van Son 2007). Because they were either already well known or most often gathered from the wild, these plants pose fewer challenges to the plant health professional than do plants from Africa, Asia, Latin America, or Oceania.

Some food and medicinal plants of the Native Americans, utilized for centuries to millennia prior to arrival of Europeans and others, are also underinvestigated for microbial associates.
WRPIS is currently collaborating with Washington State University on cataloguing fungal associates, including pathogens, of camas (Camassia quamash), long a major food for Native Americans but largely ignored by immigrants (Freed 2016). It is ironic that this plant, utilized in the PNW for many centuries, suffers the same status with respect to disease management as do plants originally imported from Africa, Asia, Oceania, or Latin America and utilized by immigrants from those regions. Other specialty crops from the Native American tradition are better documented in SMML (e.g., Jerusalem artichoke, Helianthus tuberosus) and have corresponding literature on disease management (e.g., Dugan and Miles 2016). Also cultivated by Native Americans was the pawpaw (Asimina triloba), now regarded as an emerging fruit crop (Hummer et al. 2012, with comments on some fruit diseases), and for which there is an abundance of records in SMML from North America. If a plant becomes grown commercially, documentation on pests and diseases considerably improves; see, for example, OrtizHernández and Carrillo-Salazar (2012) on fungal pathogens of pitahaya (dragonfruit, American cacti, Hylocereus spp.), long grown in Mayan and Mestizo family gardens in Mexico and Central America for food and medicine (De Clerck and Negreros-Castillo 2000; Neulinger et al. 2013). Of course, several food plants of the Americas, such as maize, potato, and many others, long ago became mainstream crops, and documentation on pests and diseases is abundant.

\section{CONCLUSION}

Whether of Asian, African, Latin American, Oceanian, or Native American origins, many emerging crops pose challenges because of their unfamiliarity to North American plant health professionals. Their inclusion in works of greater compass (e.g., Koike et al. 2007), or targeted synopses such as this one (Table 1), should be an asset to plant health professionals. Proactive awareness of emerging crops and vigilance by extension agents, diagnosticians, and others will be essential for integrating these crops and their growers into conventional 
and organic agriculture. The latter may be especially important, given the obstacles to registration of pesticides for crops of limited acreage. A forthcoming publication from the American Phytopathological Society, the Compendium of Herb Diseases and Pests, will address some emerging herb crops as well as the more familiar herbs (Robert Harveson, personal communication). Progress in documenting pathogens of these emerging crops, and devising corresponding disease management strategies, will simultaneously enable food security and enjoyment of a rich, global culinary diversity.

\section{Acknowledgments}

The authors thank Achour Amiri, Rachel Bomberger, and Carol Stiles for helpful remarks on the manuscript.

\section{Literature Cited}

Adekunle, B., Filson, G., Sethuratnam, S., and Cidro, D. 2011. Acculturation and consumption: Examining the consumption behavior of people of Afro-Caribbean descent in Canada. J. Agric. Food Syst. Community Dev. 1:297-313.

Attanayake, R. N., Dugan, F. M., Chen, W., Glawe, D. A., and McPhee, K. E. 2010. Potential alternative hosts for the pea powdery mildew pathogen Erysiphe trifolii. Pisum Genet. 42:18-19.

Berbee, M. L., Pirseyedi, M., and Hubbard, S. 1999. Cochliobolus phylogenetics and the origin of known, highly virulent pathogens, inferred from ITS and glyceraldehyde-3phosphate dehydrogenase gene sequences. Mycologia 91:964-977.

Brown, P. L. 2011. When the uprooted put down roots. New York Times. www. nytimes.com/2011/10/10/us/refugees-in-united-states-take-up-farming.html

Cerkauskas, R. F., Stobbs, L. W., Lowery, D. T., Van Driel, L., Liu, W., and VanSchagen, J. 1998. Diseases, pests, and abiotic problems associated with oriental cruciferous vegetables in southern Ontario in 1993-1994. Can. J. Plant Pathol. 20:87-94.

Chang, K.-F., Hwang, S.-F., Howard, R., and Blade, S. 1999. Diseases of Echinacea on the Canadian prairies. Alberta Agriculture and Rural Development. www1.agric.gov.ab.ca/\$department/deptdocs.nsf/all/agdex578

Chavan, S. P., and Korekar, S. L. 2011. A survey of some medicinal plants for fungal diseases from Osmanabad District of Maharashtra State. Recent Res. Sci. Technol. 3:15-16.

Chen, W., Sharma, H. C., and Muehlbauer, F. J. 2011. Compendium of Chickpea and Lentil Diseases and Pests. APS Press, St. Paul, MN.

Chen, X., Ye, H., Yan, J., Qin, Y., and Wu, G. 2006. Investigation on diseases of medicinal plants in Sichuan province and pathogen identification. Southwest China J. Agric. Sci. 19:58-62 (In Chinese).

Corlett, J. L., Dean, E. A., and Grivetti, L. E. 2003. Hmong gardens: Botanical diversity in an urban setting. Econ. Bot. 57:365-379.

Coulter, L. 2006. Gardening with Heirloom Seeds: Tried-and-True Flowers, Fruits, and Vegetables for a New Generation. University of North Carolina Press, Chapel Hill.

da Silva, W. L., and Singh, R. 2012. First report of Alternaria alternata causing leaf spot on Aloe vera in Louisiana. Plant Dis. 96:1379.

Davidson, J. A., Pande, S., Bretag, T. W., Lindbeck, K. D., and Kishore, G. K. 2004. Biology and management of Botrytis spp. in legume crops. Pages 295-318 in: Botrytis: Biology, Pathology and Control. Y. Elad, B. Williamson, P. Tudzynski, and N. Delen, eds. Kluwer Academic Publishers, Dordrecht, the Netherlands.

De Clerck, F. A. J., and Negreros-Castillo, P. 2000. Plant species of traditional Mayan homegardens of Mexico as analogs for multistrata agroforests. Agrofor. Syst. 48:303-317.

Dugan, F. M., and Miles, C. A. 2016. White mold of Jerusalem artichoke. Cooperative Extension Fact Sheet ES208E. Washington State University, Pullman.

Erwin, D. C., and Ribeiro, O. K. 1996. Phytophthora Diseases Worldwide. APS Press, St. Paul, MN.

Farr, D. F., and Rossman, A. Y. n.d. Fungal databases. Systematic Mycology and Microbiology Laboratory (SMML), ARS, USDA. https://nt.ars-grin.gov/ fungaldatabases/

Freed, G. 2016. Effect of temperature on virulence of fungal isolates collected in mycofloristic survey of Camassia quamash. Phytopathology 106:S4.198.

Gahukar, R. T. 2012. Evaluation of plant-derived products against pests and diseases of medicinal plants: A review. Crop Prot. 42:202-209.

Gandonou, J. M., and Waliczek, T. M. 2013. An analysis of the recent trends in U.S. chile pepper production, consumption and imports. J. Food Agric. Environ. 11:361-367.

Girma, K., Reinert, M., Ali, M. S., Sutradhar, A., and Mosali, J. 2012. Nitrogen and phosphorus requirements of teff grown under dryland production system. Crop Manag. 11(1).
Glawe, D. A. 2004. First report of powdery mildew of Hypericum perforatum (St. John's wort) caused by an anamorphic Microsphaera species in the Pacific Northwest. Plant Health Prog. "^journal")

Govindasamy, R., Van Vranken, R., Sciarappa, W., Ayeni, A., Puduri, V. S., Pappas, K., Simon, J. E., Mangan, F., Lamberts, M., and McAvoy, G. 2010. Ethnic crop opportunities for growers on the East Coast: A demand assessment. J. Ext. 48:1-9.

Gupta, P. K., Singh, D., Sharma, N. D., and Gharde, Y. 2010. New host records of cercosporoids from medicinal plants of Madhya Pradesh. Indian Phytopathol. 63:357-359

Habibi, A., Peever, T. L., Banniza, S., and Morrall, R. A. A. 2016. First report of Ascochyta blight of fenugreek (Trigonella foenum-graecum) caused by Peyronellaea pinodes in Canada. Plant Dis. 100:520.

Harveson, R. M., Markell, S. G., Goswami, R., Urrea, C. A., Burrows, M. E., Dugan, F., Chen, W., and Skoglund, L. G. 2011. Ascochyta blight of chickpeas. Plant Health Prog. "^journal")

Hightower, L. S., and Brennen, M. A. 2013. Local food systems, ethnic entrepreneurs, and social networks. Agricultural and Applied Economics Association, 2013 AAEA and CAES Joint Annual Meeting, Washington, DC, August 4-6, 2013. http:// ageconsearch.umn.edu/record/149696/files/Local\%20Food\%20Systems_\%20Ethnic $\% 20$ Entrepreneurs_\%20and\%20Social\%20Networks\%20-\%20Hightower_L.pdf

Hodge, W. H., and Erlanson, C. O. 1956. Federal plant introduction: A review. Econ. Bot. 10:299-334

Hondagneu-Sotelo, P. 2014. Paradise Transplanted: Migration and the Making of California Gardens. University of California Press, Berkeley. "^journal")

Hummer, K. E., Pomper, K. W., Postman, J., Graham, C. J., Stover, E., Mercure, E. W., Aradhya, M., Crisosto, C. H., Ferguson, L., Thompson, M. M., Byers, P., and Zee, F. 2012. Emerging fruit crops. Pages 97-147 in: Fruit Breeding. M. L. Badenes and D. H. Byrne, eds. Springer, New York. "^journal")

Hyland, H. L. 1977. History of U.S. plant introduction. Environ. Rev. 4:26-33.

Imbruce, V. 2007. Bringing Southeast Asia to the Southeast United States: New forms of alternative agriculture in Homestead, Florida. Agric. Human Values 24:41-59.

Ji, P., Yin, J., and Jackson, K. L. 2012. First report of root rot caused by Fusarium solani on Benincasa hispida in the United States. Plant Dis. 96:294.

Kaiser, W. J., and Hannan, R. M. 1987. First report of Mycosphaerella rabiei on chickpeas in the western hemisphere. Plant Dis. 71:192.

Kaiser, W. J., and Muehlbauer, F. J. 1984. Occurrence of Aschochyta rabiei on imported chickpeas in eastern Washington. Phytopathology 74:1139.

Kaiser, W. J., Wang, B.-C., and Rogers, J. D. 1997. Ascochyta fabae and A. lentis: Host specificity, teleomorphs (Didymella), hybrid analysis, and taxonomic status. Plant Dis. 81:809-816.

Keinath, A. P., Rushing, J. W., and Dufault, R. J. 1999. First report of Southern blight, caused by Sclerotium rolfsii on St. John's wort. Plant Dis. 83:696.

Kim, H.-J. 2016. Opportunities and challenges of alternative specialty crops: The global picture. HortScience 51:1316-1319.

Koike, S. T. 1994. First report of stem rot of fennel in the United States caused by Sclerotinia minor. Plant Dis. 78:754E.

Koike, S. T. 1996. Outbreak of white rust, caused by Albugo candida, on Japanese mustard and tah tsai in California. Plant Dis. 80:1302.

Koike, S. T. 1997. Broccoli raab as a host of Alternaria brassicae in California. Plant Dis. 81:552.

Koike, S. T. 1998. Downy mildew of arugula, caused by Peronospora parasitica, in California. Plant Dis. 82:1063.

Koike, S. T. 1999. Stem and crown rot of chervil, caused by Sclerotinia sclerotiorum, in California. Plant Dis. 83:1177.

Koike, S. T. 2003. Sclerotinia stem and crown rot of corn-salad caused by Sclerotinia minor in California. Plant Dis. 87:1264.

Koike, S. T. 2008. Downy mildew caused by Peronospora valerianellae on corn-salad (Valerianella locusta) in California. Plant Dis. 92:1470.

Koike, S. T., and Butler, E. E. 1998. Leaf spot of radicchio caused by Alternaria cichorii in California. Plant Dis. 82:448.

Koike, S. T., Butler, E. E., and Greathead, A. S. 1992. Occurrence of Cercosporidium punctum on fennel in California. Plant Dis. 76:539C.

Koike, S. T., and Daugovish, O. 2012. Gray mold of green shiso (Perilla frutescens), caused by Botrytis cinerea, in California. Plant Dis. 96:908.

Koike, S. T., Gladders, P., and Paulus, A. O. 2007. Vegetable Diseases, a Color Handbook. Academic Press, Burlington, MA.

Koike, S. T., and Gordon, T. R. 2005. First report of Fusarium wilt of cilantro caused by Fusarium oxysporum in California. Plant Dis. 89:1130.

Koike, S. T., Gordon, T. R., and Kirkpatrick, S. C. 2012. First report of Fusarium stem and crown rot of fennel in Arizona caused by Fusarium avenacearum. Plant Dis. 96:145.

Koike, S. T., and Molinar, R. H. 1997. Daikon (Raphanus sativus cv. longipinnatus) as a host of Alternaria brassicae in California. Plant Dis. 81:1094.

Koike, S. T., and Saenz, G. S. 2004. First report of powdery mildew caused by Erysiphe heraclei in chervil in California. Plant Dis. 88:1163. 
Koike, S. T., and Smith, R. F. 1998. First report of powdery mildew caused by Sphaerotheca fusca on tomatillo in California. Plant Dis. 82:711.

Ladizinsky, G., and Abbo, S. 2015. The Search for Wild Relatives of Cool Season Legumes. Springer, Heidelberg, Germany. "^journal")

Landry, E. J., Coyne, C. J., and Hu, J. 2015a. Agronomic performance of springsown faba bean in southeastern Washington. Agron. J. 107:574-578.

Landry, E. J., Coyne, C. J., McGee, R. J., and Hu, J. 2016. Adaption of autumnsown faba bean germplasm to southeastern Washington. Agron. J. 108: 301-308.

Landry, E. J., Lafferty, J. E., Coyne, C. J., Pan, W. L., and Hu, J. 2015 b. Registration of four winter-hardy faba bean germplasm lines for use in winter pulse and cover crop development. J. Plant Regist. 9:367-370.

Leppik, E. E. 1960. Cercospora traversiana and some other pathogens of fenugreek new to North America. Plant Dis. Rep. 44:40-44.

McCullough, D. G., Work, T. T., Cavey, J. F., Liebhold, A. M., and Marshall, D. 2006. Interceptions of nonindigenous plant pests at US ports of entry and border crossings over a 17-year period. Biol. Invasions 8:611-630.

McGee, D. C. 1997. Plant Pathogens and the Worldwide Movement of Seeds. APS Press, St. Paul, MN.

McPartland, J., and Hosoya, T. 1998. Species of Colletotrichum on ginseng (Panax). Mycotaxon 67:3-8.

Miles, C., and Hu, J. 2014. Edamame and faba bean production: A new look at old crops. Proceedings from the Empire State Producers Expo, Syracuse, N.Y. www.hort.cornell.edu/expo/2014proceedings.php

Molinar, R. H. 2012. Indigenous Asian specialty vegetables in the Central Valley of California. HortScience 47:835-838.

Mucz, M. 2012. Baba's Kitchen Medicines: Folk Remedies of Ukrainian Settlers in Western Canada. University of Alberta Press, Edmonton.

Muehlbauer, F. J., Kaiser, W. J., Bezdicek, D. F., Morrison, K. J., and Swan, D. G. 1982. Description and culture of chickpeas. Cooperative Extension publication EB1112. Washington State University, Pullman.

Muehlbauer, F. J., Kaiser, W. J., and Simon, C. J. 1994. Potential for wild species in cool season food legume breeding. Pages 531-539 in: Expanding the Production and Use of Cool Season Food Legumes. F. J. Muehlbauer and W. J. Kaiser, eds. Springer, Dordrecht, the Netherlands. "^journal")

National Agricultural Statistics Service (NASS). 2017. Acreage. https://usda. mannlib.cornell.edu/usda/current/Acre/Acre-06-30-2017.pdf.

Nawaratne, Y. 2012. Ethno-cultural Vegetables in Ontario: Understanding the Value Chain. M.S. thesis. University of Guelph, ON.

Neulinger, K., Vogel, C. R., and Alayón-Gamboa, J. A. 2013. Plant species and their uses in homegardens of migrant Maya and mestizo smallholder farmers in Calakmul, Campeche, Mexico. J. Ethnobiol. 33:105-124.

Ni, M., Liu, T., Ding, Y., Zheng, L., Huang, J., and Hsiang, T. 2010. A leaf spot of figwort (Scrophularia ningpoensis) caused by a Phoma sp. Can. J. Plant Pathol. 32:493-495.

Nishijima, K. A., Wall, M. M., Chang, L. C., Wei, Y., and Wong, D. K. W. 2011. First report of Mucor circinelloides on noni (Morinda citrifolia) in Hawaii. Plant Dis. 95:360.

Ortiz-Hernández, Y. D., and Carrillo-Salazar, J. A. 2012. Pitahaya (Hyalocereus spp.): A short review. Comun. Sci. 3:220-237.

Patel, J. S., Costa de Novaes, M. I., and Zhang, S. 2014. First report of Colletotrichum higginsianum causing anthracnose of arugula (Eruca sativa) in Florida. Plant Dis. 98:1269.

Peever, T. L., Barve, M. P., Stone, L. J., and Kaiser, W. J. 2007. Evolutionary relationships among Ascochyta species infecting wild and cultivated hosts in legume tribes Cicereae and Vicieae. Mycologia 99:59-77.

Peichowski, K., Rizvi, S., and Reese, R. N. 1997. First report of Fusarium oxysporum on purple coneflower. Plant Dis. 81:227.

Punithalingam, E., and Holliday, P. 1975. Ascochyta fabae. CMI Descr. Pathog. Fungi Bacteria 461:1-2.

Punja, Z. K. 1997. Fungal pathogens of American ginseng (Panax quinquefolium) in British Columbia. Can. J. Plant Pathol. 19:301-306.

Putnam, M. L. 2000. First report of leaf blight and stem dieback of St. John's wort caused by Diploceras hypericum in Oregon. Plant Dis. 84:1250.

Putnam, M. L., and du Toit, L. J. 2003. First report of Alternaria blight caused by Alternaria panax on ginseng (Panax quinquefolius) in Oregon and Washington, USA. Plant Pathol. 52:406.
Raabe, R. D., Conners, I. L., and Martinez, A. P. 1981. Checklist of Plant Diseases In Hawaii. Information Text Series No. 22. College of Tropical Agriculture and Human Resources, University of Hawaii, Honolulu.

Ragone, D. 1997. Breadfruit, Artocarpus altilis (Parkinson) Fosberg. Promoting the Conservation and Use of Underutilized and Neglected Crops, 10. International Plant Genetic Resources Institute, Rome.

Reeleder, R. D. 2007. Rhexocercosporidium panacis sp. nov., a new anamorphic species causing rusted root of ginseng (Panacis quinquefolius). Mycologia 99:91-98.

Richardson, H. 2008. Ascochyta leaf and pod spot of faba bean. Agriculture Victoria Note AG0151. http://agriculture.vic.gov.au/agriculture/pests-diseases-and-weeds/ plant-diseases/grains-pulses-and-cereals/ascochyta-blight-of-faba-bean.

Richardson, M. J. 1990. An Annotated List of Seed-Borne Diseases, 4th Ed. International Seed Testing Association, Zurich.

Ripley, B. D., Ritcey, G. M., Harris, C. R., Denommé, M. A., and Lissemore, L. I. 2003. Comparative persistence of pesticides on selected cultivars of specialty vegetables. J. Agric. Food Chem. 51:1328-1335.

Rooney-Latham, S., Blomquist, C. L., and Turney, J. 2009. First report of downy mildew caused by Peronospora trigonellae on fenugreek in the United States. Plant Dis. 93:1349.

Sano, M., Susuki, K., Kobayashi, T., and Natsuaki, K. T. 2009. Survey on fungal diseases of medicinal plants in Japan. J. Int. Soc. Southeast Asian Agric. Sci. 15:257.

Scheck, H. J., and Koike, S. T. 1999. First occurrence of white rust of arugula, caused by Albugo candida. Plant Dis. 83:877.

Sciarappa, W. J., Simon, J., Govindasamy, R., Kelley, K., Mangan, F., Zhang, S., Arumugam, S., Nitzsche, P., Van Vranken, R., Komar, S., Ayeni, A., McAvoy, G., Park, C., Reichert, W., Byrnes, D., Wu, Q., and Shilling, B. 2016. Asian crops overview: Consumer preference and cultivar growth on the east coast of the United States. HortScience 51:1344-1350.

Sholberg, P. L., and Li, T. S. C. 1999. First report of powdery mildew, caused by Erysiphe cichoracearum on coneflowers. Plant Dis. 83:694.

Stanghellini, M. E., Rasmussen, S. L., and Barta, D. J. 1990. Thielaviopsis root rot of corn-salad. Plant Dis. 74:81.

Stokker, K. 2007. Remedies and Rituals: Folk Medicine in Norway and the New Land. Minnesota Historical Society Press, St. Paul, MN.

Testen, A. L., and Backman, P. A. 2012. First report of quinoa downy mildew caused by Peronospora variabilis in the United States. Plant Dis. 96:146.

Testen, A. L., McKemy, J. M., and Backman, P. A. 2013a. First report of Passalora leaf spot of quinoa caused by Passalora dubia in the United States. Plant Dis. 97:139.

Testen, A. L., McKemy, J. M., and Backman, P. A. 2013b. First report of Ascochyta leaf spot of quinoa caused by Ascochyta sp. in the United States. Plant Dis. 97:844.

Tubene, S. L., and Myers, R. D. 2008. Ethnic and Specialty Vegetables Handbook, 2nd Ed. University of Maryland Extension, Keedysville.

University of Maryland Extension. 2013. Commercial Vegetable Production Recommendations. Publication EB-236. University of Maryland Extension, Keedysville.

USDA Specialty Crop Block Grant Program. 2016. Description of funded projects (p. 72). https://www.ams.usda.gov/sites/default/files/media/ SCBGP2016DescriptionofFundedProjects.pdf

Van Son, C. R. 2007. Ethnomedicine use by older adults from a Slavic community. Commun. Nurs. Res. 40:1-7.

Wang, S. L., and Cerkauskas, R. F. 1999. Recent development of production and processing of oriental vegetables in Canada. Acta Hortic. 483:429-436.

Wyenandt, C. A., Kuhar, T. P., Hamilton, G. C., VanGessel, M. J., and Sanchez, E. 2017. Mid-Atlantic Commercial Vegetable Production Recommendations. EB-236. University of Maryland Extension, Keedysville.

Zhang, J., Wu, M. D., Li, G. Q., Yang, L., and Jiang, D. H. 2010. Botrytis fabiopsis, a new species causing chocolate spot of broad bean in central China. Mycologia 102:1114-1126.

Zhang, L., Wang, G., Zhang, F., and Zhu, S. 2013. Soaking seeds in methyl jasmonate or benzothiadiazole induces resistance to an insect pest and stem decay in Brassica campestris L. ssp. chinensis. J. Hortic. Sci. Biotechnol. 88:715-720.

Zhang, S., Fu, Y., Mersha, Z., Mo, X., and Palmateer, A. J. 2011. First report of a leaf spot on Basella alba caused by a Bipolaris sp. in Florida. Plant Dis. 95:880. 